\begin{tabular}{|lcl|}
\hline & Uniqbu Journal Of Social Sciences (UJSS) & \\
\hline Volume 1 & Nomor 1, April 2020 & Halaman $61-71$ \\
\hline
\end{tabular}

\title{
ASPEK SPIRITUAL DALAM NOVEL TUHAN IZINKAN AKU MENJADI PELACUR KARYA MUHIDIN M DAHLAN \\ (Spiritual Aspects In The Lovely Of God Let Me Become A Property Of Muhidin M \\ Dahlan)
}

\author{
Karim $^{\mathrm{a},}$, Asman Budiman ${ }^{\mathrm{b}}$, Muhammad Yusnan ${ }^{\mathrm{c}} \&$ Taufik $^{\text {d }}$ \\ ${ }^{\text {ab }}$ Institut Agama Islam Negeri Kendari \\ Jl. Sultan Qaimuddin No.17, Baruga, Kota Kendari, Sulawesi Tenggara 93563, Indonesia \\ ${ }^{\mathrm{c}}$ Universitas Muhammadiyah Buton \\ Jl. Betoambari, Lanto, Batupoar, Kota Bau-Bau, Sulawesi Tenggara 93724 \\ ${ }^{\mathrm{d}}$ Universitas Iqra Buru \\ Pos-el: karim@iainkendari.co.id
}

(Diterima: 12 April; Direvisi 17 April; Disetujui: 20 April 2020)

\begin{abstract}
Abstrak
Karya sastra merupakan wadah dari ide, gagasan, serta seorang pengarang mengenai gejala sosial yang ditangkap dan dialami pengarang yang dituangkan dalam bentuk karya. Penelitian ini bertujuan untuk mendeskripsikan aspek spiritualitas dalam Novel Tuhan Izinkan Aku Menjadi Pelacur! karya Muhidin M Dahlan. Metode dalam penelitian ini adalah deskriptif kualitatif. Penelitian kualitatif dilakukan dengan mengutamakan kedalaman penghayatan terhadap interaksi antara konsep yang sedang dikaji secara empiris. Hasil penelitian menunjukan bahwa aspek spiritual yang terdapat dalam novel Tuhan Izinkan Aku Menjadi Pelacur! Adalah Aqidah, syariah, dan akhlak. Akidah terdiri dari ketauhidan dan iman kepada takdir. Syariah meliputi ibadah dan siyasah sedankan muamalah dan munakahat tidak ditemukan. Adapun akhlak mencakup akhlak kepada Allah, akhlak kepada kedua orang Tua, dan akhlak dalam menerima ketentuan Allah sedangkan perasaan malu (Al-Haya) tidak ditemukan. Selain itu juga ditemukan suatu perasaan keagamaan yang lebih mengarah pada eksistensinya sebagai manusia karena bersifat personalitas dan cakupannya pun lebih luas dari pada agama yang hanya terbatas pada ajaran-ajaran dan pertautan-pertautan.
\end{abstract}

Kata Kunci: Spritual, Novel Tuhan Izinkan Aku Menjadi Pelacur

\begin{abstract}
Literary work is a container of ideas, ideas, and an author about social phenomena that are captured and experienced by the author as outlined in the form of work. Research describes aspects of spirituality in God's Novel Let Me Become a Prostitute! the work of Muhidin M Dahlan. The method in this research is descriptive qualitative. Qualitative research is conducted by prioritizing the depth of appreciation of the interaction between concepts being studied empirically. The results showed that the spiritual aspects contained in the novel Lord Let Me Be a Prostitute! Is Aqeedah, sharia, and morals. Aqeedah consists of monotheism and faith in destiny. Sharia includes worship and siyasa while muamalah and munakahat are not found. As for the morals include the morals to God, the morals for both parents, and the morals in accepting Allah's provisions while the feeling of shame (Al-Haya) is not found. It also found a religious feeling that is more directed to its existence as a human being because it is personal in nature and its scope is broader than religion which is only limited to the teachings and links.
\end{abstract}

Keywords: Spiritually, God's Novels Allow Me to Be a Prostitute 


\section{PENDAHULUAN}

Karya sastra novel merupakan bagian dari prosa yang dekat dengan masyarakat karena jalan ceritanya tidak jauh dari realitas kehidupan masyarakat. Novel memiliki cerita yang mengemukakan suatu cerita secara bebas, menyajikan sesuatu secara lebih banyak, lebih rinci, lebih detail dan lebih banyak melibatkan berbagai permasalahan yang lebih kompleks. Biasanya juga melukiskan suka, duka, cinta dan adat istiadat.

Selain itu juga karya satra memberikan pesan moral yang berwujud nilai spiritual. Nilai sangat mempengaruhi prilaku dan tindakan manusia baik yang dilakukan secara perorangan maupun kelompok. Nilai spiritualitas dalam karya sastra sangat diperlukan karena sastra tumbuh dari sesuatu yang bersifat spiritual.

Dengan adanya aspek spiritual, dapat memberi kesadaran batin untuk membuat kebaikan, dan perlu ditanamkan kesadaran tentang pemahaman dan penghayatan terhadap nilai spiritual terutama pada zaman globalisasi sekarang ini sangat diperlukan sebuah karya fiksi berupa novel atau roman memiliki nilai spiritual sebagai pembangun Iman.

Perkembangan novel di Indonesia dari zaman dulu sampai sekarang banyak yang bertemakan masalah-masalah yang berhubungan dengan keagamaan, Karena agama merupakan hal yang sangat penting dalam kehidupan. Berkaitan dengan hal ini, dalam novel Tuhan Izinkan Aku Menjadi Pelacur digambarkan terutama tentang kehidupan tokoh utama dengan menjalani kehidupan muslimah yang taat, tetapi di tengah jalan ia diterpa badai kekecewaan. Dalam keadaan kosong itulah ia terjerembab dalam dunia hitam.

Dalam novel Tuhan Izinkan Aku Menjadi Pelacur pengarang mencoba menyajikan kisah petualangan seorang muslimah yang melintasi berbagai aspek kehidupan. Selain itu novel ini juga disajikan dengan gaya bahasa yang sederhana namun sangat menggugah. Penulis juga berhasil menghadirkan tokoh-tokoh dan suasana dengan begitu hidup dan kritis. Hal inilah yang melatarbelakangi penulis melakukan penelitian dengan judul "Analisis Spiritualitas Islami pada tokoh utama dalam novel Tuhan Izinkan Aku Menjadi Pelacur! Karya Muhidin M Dahlan”.

\section{LANDASAN TEORI}

Karya sastra merupakan wadah dari ide, gagasan, serta seorang pengarang mengenai gejala sosial yang ditangkap dan dialami pengarang yang dituangkan dalam bentuk karya. Berdasarkan hal tersebut, jelas bahwa kesusastraan terkait erat dengan ilmu sosial yang di dalamnya mempertimbangkan aspek-aspek kemasyarakatan.

Karya sastra merupakan deskripsi pengalaman kemanusiaan yang memiliki demensi individu dan sosial kemasyarakatan sekaligus karena itu, pengalaman dan pengetahuan kemanusia-an tidaklah sekedar menghadirkan dan memotret begitu saja, melainkan secara substansi menyarankan bagaimana proses kreasi kreatif pengarang dalam mengeksprsikan gagasan-gagasan keindahannya. Gagasan-gagasan keindahanya ini, dapatlah dikatakan berfungsi ganda, untuk mengomunikasikan kenikmatan estetik dan bagaimana manusia (pembaca atau penikmat) menemukan kehidupan itu sendiri dalam figurasi estetis dunia yang lain. (Suwadah, 2011: 2)

Pendekatan struktural dalam penelitian ini diambil berdasarkan unsur-unsur yang membangun teks karya sastra itu sendiri. Sebagaimana diungkapkan oleh Zerafta bahwa "bentuk dan isi karya sastra diambil dari fenomena social dibandingkan dengan seni yang lain, kecuali film. Oleh karena itu, karya sastra seringkali tampak terikat dengan momen khusus dalam sejarah masyarakat" Zerafta dalam (Elizabeth dan Zainuddin Fananie, 2000: 133). Untuk dapat 
memahami karya sastra diperlukan pertama, menelaah karya sastra tersebut dari segi struktur yang membangunnya. Kedua, menelaah karya sastra dari konteks eksternalnya.

Struktur karya sastra ditujukan untuk menafsirkan teks yang akan mendapatkan makna tepat apabila diketahui unsur-unsur pembangunnya. Hal ini dikarenakan novel yang dibangun dari sejumlah unsur akan saling berhubungan secara saling menentukan sehingga akan menyebabkan novel tersebut menjadi sebuah karya yang bermakna hidup.

Konteks eksternal karya sastra dalam penelitian ini adalah aspek kepengarangan dan aspek sosial yang dimaksudkan untuk melihat kenyataan sosiologis kepengarangan novel Tuhan Izinkan Aku Menjadi Pelacur! Karya Muhidin M Dahlan, sehingga dapat diketahui hubungan karya sastra dalam hubungannya dengan realita di masyarakat. Konteks eksternal yang sebenarnya ada di luar karya sastra itu, cukup membantu para penelaah sastra dalam memahami dan menikmati karya yang dihadapi. Pengalaman mendalam dan pengenalan konteks eksternal tersebut memungkinkan seseorang penelaah mampu menginterpretasi karya sastra dengan lebih tepat. Konteks eksternal dapat disebut mempunyai nilai estetik, jika pengarang mampu menuangkannya dalam satu rangkaian ide yang termanifestasi dari karakter tokoh, persoalan yang dihadapi, pemecahan persoalan, tanpa harus menggurui pembaca.

\section{A. Spiritualitas}

Kamus Besar Bahasa Indonesia, (2008: 419) Spiritualitas adalah kepercayaan akan adanya kekuatan adikodrati di atas manusia atau kepercayaan (animism, dinamisme, dan sebagainya). Sedangkan religius adalah bersifat religi; bersifat keagamaan; yang bersangkut paut dengan religi.

Mangunwijaya, mengatakan bahwa konsep keagamaan manusia bersikap
(2002:

Spiritualitas adalah yang menyebabkan religius. Religius merupakan bagian dari kebudayaan dan sistem dari suatu agama yang satu dengan agama yang lain memiliki sistem religi yang berbeda. Spiritualitas islami merupakan wujud seseorang berdoa untuk yakin dan percaya kepada Tuhan sehingga keadaan emosi mengalami ketenanga dan kedamaian. Keterkaitan manusia terhadap Tuhan sebagai sumber ketentraman dan kebahagiaan dengan melakukan tindakan sesuai dengan ajaran-ajaran agama. Kaitan agama dengan masyarakat banyak dibuktikan oleh pengetahuan agama dalam argumentasi rasional tentang arti dan hakikat kehidupan, tentang kebesaran Tuhan dalam arti mutlak, dan kebesaran manusia dalam arti relatif selaku makhluk. Spiritualitas adalah hubungannya dengan Yang Maha Kuasa, tergantung dengan kepercayaan yang dianut oleh individu. Mempunyai kepercayaan atau keyakinan berarti memercayai atau mempunyai komitmen terhadap sesuatu atau seseorang

Dalam sebuah pengantar bukunya, Nurcholis (2003: 34) mengatakan bahwa setiap manusia memiliki naluri. Spiritualitas adalah hubungannya dengan Yang Maha Kuasa, tergantung dengan kepercayaan yang dianut oleh individu. Mempunyai kepercayaan atau keyakinan berarti memercayai atau mempunyai komitmen terhadap sesuatu atau seseorang naluri untuk berkepercayaan. Naluri itu muncul bersamaan dengan hasrat memperoleh kejelasan tentang hidup dan alam raya menjadi lingkungan hidup itu karena setiap manusia pasti memiliki keinsafan apa yang dianggap "makna hidup". Makna hidup yang hakiki dan sejati itu ada.

Lebih jauh mangun wijaya (dalam Nurgiyantoro, 2001: 326-327) mengemukakan bahwa perbedaan agama dengan spiritualitas. Agama lebih menunjukkan pada kelembagaan kebaktian pada tuhan dengan hukum - hukum yang resmi. Sedangkan spiritualitas bersifat mengatasi lebih dalam dan lebih luas dari agama yang tampak, formal dan resmi. 
Spiritualitas berkaitan dengan kebebasan orang untuk menjaga kualitas keberagamannya jika dilihat dari dimensi yang paling dalam dan personal yang acapkali berada diluar kategori-kategori ajaran agama. (Ratnawati dalam Susiati: 2020).

Dari uraian diatas dapat disimpulkan bahwa spiritualitas adalah suatu perasaan keagamaan yang lebih mengarah pada eksistensinya sebagi manusia karena bersifat personalitas dan cakupannya pun lebih luas dari pada agama yang hanya terbatas pada ajaran-ajaran dan pertautan-pertautan.

\section{B. Aspek-Aspek Spiritualitas}

Spiritualitas dalam konteks ini adalah ajaran islam yang meliputi beberapa unsur fundamental yaitu: Aqidah, syariah, akhlak dan ilmu Fiqh, empat hal dari unsur religi ini tidak dapat dipisahkan karena sangat berkaitan dengan yang lainnya.(Jafar, 2010: 21) Berikut akan diuraikan hal yang berkaitan dengan empat unsur tersebut:

\section{Aqidah}

Aqidah secara bahasa berarti ikatan, secara terminologi berarti landasan yang mengikat, yaitu keimanan, itu sebabnya ilmu tauhid disebut ilmu aqoid (jamak aqidah). Aqidah menurut Azra dkk (2002: 103-104) merupakan ajaran tentang apa saja yang mesti dipercayai, diyakini dan diimani oleh setiap orang islam. Oleh karena itu Aqidah merupakan ikat dan simpul dasar islam yang pertama dan utama. Menurut Rejono (2006: 67) mengatakan aqidah adalah suatu yang mengeraskan hati membenarkan yang membuat jiwa tenang dan menjadi kepercayaan yang bersih dari kebimbangan dan keraguan.

Dari pendapat-pendapat di atas disimpulkan bahwa aqidah adalah keyakinan dasar berupa ketauhidan dan iman kepada takdir yang menguatkan atau meneguhkan jiwa sehingga jiwa terbebas dari rasa kebimbangan atau keraguan di dalam Islam disebut dengan iman.

2. Syariah
Menurut Ahmadi dan Salimi (2008: 237) mendefinisikan syariah adalah tata cara atau tentang prilaku hidup manusia untuk mencapai keridhoan Allah SWT. Adapun ruang lingkup syariah mencangkup peraturan-peraturan yaitu: ibadah, muamalah, munakahat, dan siyasah. Selain itu juga menurut Ramulyo (2004:9) syariat merupakan sasaran dari ilmu pengetahuan yang khusus disebut alfiqh.Lebih jauh Syafi'i (dalam Ramulyo, 2004: 8) berpendapat bahwa syariah merupakan peraturanperaturan lahir dan bathin bagi umat islam yang bersumber pada wahyu Allah dan kesimpulan-kesimpulan (deductions) yang dapat ditarik dari wahyu Allah, dan sebagainya.Peraturan-peraturan lahir itu mengenai cara bagimana manusia berhubungan dengan Allah dan sesama makhluk lainya.

Dari pendapat-pendapat di atas dapat disimpulkan bahwa, syariah adalah tata cara atau peraturan-peraturan tentang perilaku hidup manusia secara lahir dan bathin yang menyangkut bagaimana cara manusia berhubungan dengan Allah dan dengan sesama makhluk lain untuk mencapai keridhoan Allah SWT.

3. Akhlak

Akhlak sering juga disebut dengan moral, diartikan sebagai ajaran baik buruk perbuatan atau kelakuan. Menurut Nurdin (dalam Ariani, 2010: 20) mengatakan bahwa akhlak adalah sistem nilai yang mengatur pola sikap dan tindakan manusia di atas bumi. Sistem nilai yang dimaksud adalah ajaran islam dengan Al-Qur'an dan Sunnah Rasul sebagai sumber nilainya serta ijetihad (hukum islam).Menurut Ghazali (dalam Musthofa, 2000: 12) menjelaskan akhlak adalah suatu sifat yang tertanam dalam jiwa daripadanya timbul perbuatan-perbuatan dengan mudah, dengan tidak memerlukan pertimbangan terlebih dahulu.

Hal-hal yang fundamental terkait dengan penelitian didalam akhlak yaitu: akhlak kepada Allah, akhlak kepada kedua orang Tua, akhlak dalam menerima 
ketentuan Allah, dan perasaan malu (AlHaya).

\section{Pengertian Novel}

Kata novel berasal dari kata latin novellus yang diturunkan dari kata novies yang berarti baru. Dikatakan baru karena kalau di bandingkan dengan jenis-jenis sastra lainnya seperti puisi, drama, dan lainlain, maka novel muncul kemudian (Tarigan, 2000: 164).

Sejalan dengan pernyataan di atas, Nurgiyantoro (2002: 4) berpendapat bahwa novel sebagai sebuah karya fiksi pada prinsipnya menawarkan sebuah dunia yang berisi model kehidupan yang ideal, imajiner, yang dibangun melalui berbagai unsur intrinsiknya seperti alur, tokoh, penokohan, latar, sudut pandang, dan lain-lain.

Nurgiyantoro (dalam Risman \& Susiati: 2018) mengelompokan unsur-unsur pembangun sebuah novel yang kemudian membentuk sebuah totalitas itu disamping unsur formak bahasa, masih banyak lagi macamnya. Adapun unsur pembangun novel yang dimaksud dan akan diteliti meliputi: penokohan, alur, latar, tema dan amanat.

Berdasarkan beberapa pendapat diatas, dapat disimpulkan bahwa novel merupakan karangan berbentuk prosa yang panjang dan mendetail mengenai sesuatu yang dilukiskan di dalamnya, baik jumlah halaman, ataupun peristiwa-peristiwa yang diungkapkan dan si tokoh diceritakan mulai dari kecil hingga dewasa serta mengalami perubahan nasib pada akhir cerita.

\section{METODE PENELITIAN}

Metode dalam penelitian ini adalah deskriptif kualitatif. Risman dan Harziko: 2018. menjelaskan bahwa penelitian kualitatif dilakukan dengan tidak mengutamakan angka-angka, tetapi mengutamakan kedalaman penghayatan terhadap interaksi antara konsep yang sedang dikaji secara empiris. Yang paling cocok untuk fenomena sastra adalah penelitian kualitatif.
Adapun jenis penelitian dalam penelitian ini adalah kepustakaan. Peneliti akan mendiskripsikan spiritualitas islami pada tokoh utama dalam novel Tuhan Izinkan Aku Menjadi Pelacur! Karya Muhidin M Dahlan, yang di peroleh dalam kepustakaan yang tersedia.

Sumber data dalam penelitian ini adalah sumber data tertulis yaitu novel Tuhan, Izinkan Aku Menjadi Pelacur! karya Muhidin M Dahlan terbitan SciPtaManent bekerjasama dengan Melibas, cetakan 13, mei 2009, Yogyakarta (2009). Data yang dikumpulkan dalam penelitian ini berupa kata-kata atau kalimat-kalimat.

Dalam menganalisis data dalam penelitian ini, Pendekatan yang digunakan adalah metode analisis isi. Dasar penafsiran dalam metode analisis isi memberikan perhatian pada isi pesan. Oleh karena itulah, metode analisis yang dilakukan dalam dokumen-dokumen yang padat isi. Ratna (2008: 48-49)

\section{PEMBAHASAN}

Melihat karya sastra sebagai sarana penyampaian suatu pesan yang mendidik, melalui pendekatan pragmatik peneliti berusaha mencari nilai-nilai yang terkandung dalam novel. Untuk mencapai salah satu tujuan di atas, peneliti disini mencari nilai Spiritualitas Islami pada tokoh utama dalam novel Tuhan Izinkan Aku Menjadi Pelacur!.

Aspek spiritualitas islami sudah terlihat sejak awal cerita. Bagian awal dan akhir cerita memberikan gambar kedekatan unsur tokoh dengan unsur spiritualitas. Unsurunsur spiritualitas tersebut meliputi: aqidah, syariah, dan akhlak. Untuk lebih jelasnya maka unsur tersebut akan diuraikan sebagai berikut:

\section{Aqidah}

Aqidah adalah keyakinan dasar yang menguatkan atau meneguhkan jiwa sehingga jiwa terbebas dari rasa kebimbangan atau keraguan didalam islam disebut dengan iman. Oleh karena itu, peneliti akan 
membahas hal-hal yang fundamental yang terkait dengan skripsi ini dalam aqidah adalah sebagai berikut:

\section{a. Ketauhidan}

Unsur ketauhidan sudah terlihat dari berbagai segi diantaranya melalui bimbingan pengajian di Masjid Tarbiyah, aktif dlm organisasi Keluarga Mahasiswa islam selain itu organisasi yang mencita-citakan tegaknya syariat islam yang digeluti Nidah Kirani (tokoh utama) juga banyak mendapatkan bimbingan ketauhidandan. Sebagaimana kutipan dalam novel sebagai berikut:

Maka demikianlah, selama satu setengah jam aku mendengarkan kuliah agama yang tak pernah kudapatkan sebelumnya. (hal. 28)

Di Pondok, setelah prosesi pembaiatanku usai, aku benar-benar menjalani kehidupan sufi. (hal. 51)

Aku merasakan, perjalananku, safari beragamaku akhir-akhir ini benar-benar terasa indah. Terasa teduh. Aku merasa bahwa jalan hidupku benar-benar mendapat limpahan kekuatan langsung dari Allah. Ritual ibadahku sangat keras. Puasa tiap hari. Sehabis shalat magrib aku akan berzikir hingga isya menjelang. Setelah isya shalat lagi, terus mengaji hingga capek. Kalau mau tidur, aku zikir hingga mataku sembab oleh tangis pertaubatan dan derai syukur yang terus mengiring dalam hatiku. Dan aku benarbenar sadar bahwa aku adalah hamba yang tak punya arti dihadapan Allah. Aku merasakan bahwa itulah hubungan teragungku buakn sekedar romantis dengan Tuhanku. (Hal. 53)

Pengajian itu dibuka dengan pembacaan ayat suci Alquran yang kebetulan qariah yang ditunjuk membaca ayat-ayat awal surat Al-Baqarah. Ayat itulah yang kubahas secara detail dihadapan jemaah pengajian kampung itu. Aku terjemahkan ayat itu dan kujelaskan satu demi satu yang membuat mereka terpana, ternyata Nidah Kirani anak sah kampung mereka, bisa selihai itu membahas ayat-ayat Alquran. Aku hanya ingin menunjukan kepada mereka semua bahwa Alquran itu jangan dijadikan jimat, tapi dipahami isinya agar bermanfaat bagi kehidupan. (hal. 71-72)

Kutipan di atas memaparkan bahwa Nidah Kirani (tokoh utama) begitu patuh untuk menjalankan segala perintah Allah SWT. Sehingga dalam kesehariannya menjalani kehidupan yang tenang dan apapun segala kegiatan dan keluh kesah hatinya ia mengadu kepada-Nya. Dan ketika tertimpa masalah, Nidah Kirani berserah diri kepada Allah mengharapkan agar di ampuni dosanya. Karena dia meyakini tiada yang patut ia cintai di dunia hanya Allah dan junjungan-Nya.

\section{b. Iman terhadap Takdir}

Keikhlasan hati dalam menerima segala cobaan menjadi salah satu bukti kepercayaannya terhadap Allah SWT. Sebagaimana kutipan di dalam novel sebagai berikut:

Tapi ketika kemarahan itu datang, sebuah suara membisiki dari pedalamanku bahwa segala cibiran, segala intrik adalah cobaan dan ujian dari-Nya sebelum aku menapaki jalan dakwah yang luar biasa mulianya nanti. (hal 44)

$Y a$, aku ingin seperti cadas yang telah tawakal dan pasrah diri untuk menerima gempuran-gempuran buih kenyataan yang didorong oleh badai takdir. Aku tak ingin gempuran itu melemahkanku, meluruhkanku, dan menghancurkanku. Seperti cadas, aku ingin dengan gempuran itu diriku menjadi jauh lebih kuat dari sebelim-belumnya. Tapi bisa kah aku? Bisakah aku kuat menahan segala-gala gempuran itu dengan bawaan jiwa yang labil, yang rapuh 
seperti sekarang-sekarang ini? (hal. 137)

Dengan hati yang ikhlas, Nidah Kirani menerima semua yang telah menjadi takdirnya dan perjuangannya dalam dakwah yang mencita-citakan tegaknya syariat islam di Indonesia . Karena Nidah Kirani percaya terhadap takdir Tuhan dengan sungguhsungguh serta menerima keadaan itu dengan wajar. Abas menyadari bahwa ia telah salah memberikan semua harapannya kepada orang yang tidak pantas menerimanya. Kemudian Nidah Kiranitetap memilih untuk hidup dan melanjutkan petualangannya dalam berbagai segi kehidupan.

\section{Syariah}

Menurut Ahmadi dan Salimi (2008: 237) mendefinisikan syariah adalah tata cara atau tentang prilaku hidup manusia untuk mencapai keridhoan Allah SWT. Adapun ruang lingkup syariah yangmembahas halhal yang fundamental yang terkait dengan skripsi ini adalah sebagai beerikut:

\section{a. Ibadah}

Ketekunan beribadah Nidah Kirani kepada Allah dengan beribadah dan selalu menjunjung tinggi nilai syara' serta mengingat akan hakikatnya sebagai manusia yang sebenarnya. Untuk lebih jelasnya perhatikan kutipan berikut:

Ketekunannya beribadah pun tertular kepadaku. Akupun mulai bisa shalat tepat waktu dan berjamaah di masjid yang tepat berada di depan asrama putri. Hampir dipastikan aku sudah berada di masjid ketika azan belum selesai dikumandangkan. (Hal. 29)

Sehari-hari dalam aktifitasku kuisi dengan membaca Alquran lengkap dengan terjemahannya. Kujalani ritual shalat dengan mantap. Hampir seluruh waktuku kuhabiskan untuk shalat. Bukan Cuma yang wajib, tapi juga yang sunnah, seperti rawatib dan lain sebagainya.
Paginya aku dipastikan menghadap Allah dalam shalat dhuha sambil menunggu dzuhur menjelang. Malamnya kudirikan tulang-tulangku dalam tahajud kepada-Nya. Bermalam-malam begitu yang membuat mataku sembab oleh tangis ibadah dan kerinduan kepada Allah. Tak pernah putus kugiring aktifitasku pada satu stasiun yang sama sekali tak pernah kualami sebelumnya total beribadah. Kerjaku Cuma dikamar, shalat, baca Alquran, dan berdoa. (hal. 41)

Bukankah aku hanya menuruti perintah Allah dalam Alquran surah An-Nur ayat 31 yang memerintahkan agar menutup aurat serapat-rapatnya. (hal 42)

Kutipan di atas memaparkan bahwa, Nidah Kirani begitu patuh dalam menjalankan perintah Allah SWT. Untuk menyembah sesuai dengan perintah-Nya, mengerjakan segala yang menjadi kewajiban muslim. Nidah Kirani melakukan ibadahnya dan tak lepas dari berzikir mengingat Allah.

\section{b. Siyasah}

Nidah Kirani merupakan muslimah yang paham bagaimana berislam yang sesungguhnya. Keimanan kepada Allah bukan sekedar bemakna percaya akan adanya Allah, tapi harus disertai ketundukan pada segenap dan seluruh aturannya. Seorang muslim yang mengatakan dirinya sebagai muslim harus menjadi muslim secara keseluruhan, secara kaffah. Nidah Kirani gencar berdakwah demi tegaknya syariat islam di Indonesia. Sebagaimana dalam kutipan berikut:

Karena itu, apa saja hukum yang digali dari sumber-sumber hukum islam bisa digolongkan sebagai sumber hukum syariat. Jadi sudah jelas, syariat bukan hanya soal rajam bagi pezina, potong tangan bagi maling, atau segala hal yang sifatnya kriminil atau apa yang 
diistilahkan hudud, tapi juga seтиa aturan yang mengatur semua aspek kehidupan manusia.

"Nah, untuk menegakkan semua itu bagaimana? Disinilah perlunya kalian kukumpulkan, kuseru-seru agar sadar memikul tugas penegakan itu. Kutegaskan sekarang, "wajahku dekatkan pada barisan mereka yang duduk melingkar dan suaraku kupelankan, "kita butuh negara untuk menyukseskan tegaknya syariat itu. Kalian semua mesti tahu bahwa tak akan pernah ada kemuliaan kecuali dengan islam, dan tak ada islam kecuali dengan sysriat dan tak ada syariat kecuali dengan daulah." (hal. 74)

Duh Gusti Allah, fitnahan apalagi yang mereka sodorkan ini? Mengapa mereka bisa berpikiran seperti itu? Pahamkah mereka bahwa Indonesia membutuhkan daulah yang berqanunkan islam?tidakkah indah bumi indonesia ini apabila dilindungi hukum-hukum islam dan tidak gampang dijewer dan ditetak oleh kekuasaan asing seperti Amerika. Tapi mereka, mereka.... duh Gusti Allah, bukakanlah hati mereka, pikiran orangorang kampung yang belum bisa berislam secara kaffah ini! (hal. 79)

Dari kutipan diatas jelaslah bahwa Nidah Kirani merupakan aktifis islam yang berjuang demi tegaknya syariat islam di Indonesia. Dalam perjuangan dahwahnua ia tak kenal lelah, bahkan ia rela memberikan segala apa yang dimilikinya baik berupa tenaga, pikiran bahkan materi.

\section{Akhlak}

Akhlak merupakan tingkah laku, budi pekerti yang melekat dalam jiwa seseorang untuk melakukan hal atau perbuatan.Inti dari akhlak adalah tingkah laku baik dan buruk dari seorang muslim. Oleh sebab itu, peneliti akan membahas masalah tingkah laku atau perbuatan yang dimaksud dari definisi akhlak di atas, antara lain sebagai berikut:

\section{a. Akhlak kepada Allah}

Pada permulaan petualangan Tokoh Nidah Kirani dalam setiap mengambil keputusan selalu berakhlak kepada Allah untuk tetap tunduk atas apapun yang telah terjadi kepadanya. Ketundukan tersebut dapat diungkapkan dari tata cara, tingkah laku, maupun perkataannya. Sebagaiman kutipan tersebut yaitu:

Ya Allah, singkapkan wajah-Mu kepada hamba dalam tirai senyap malam yang bergemintang dan bercahaya. (Hal. 41)

Ya Allah, kalau memang ini kebenaran, berilah ketetapan hatiku. Aku yakin seyakin-yakinnyan ya Allah, bahwa hukum-hukum Islam itu harus ditegakkan demi tegaknya ayat-ayatMu. (Hal. 42)

Aku memanjatkan doa terakhir dimalam yang terakhir dan di pintu gerbang siang pertama pengembaraan menuju kehidupan bumi yang makin tua makin gelap. "oh Tuhan, izinkan aku mencintai-Mu dengan cara yang lain, menerima kehidupan dengan sepenuh kejujuran. Seperti gemericik air di pematang sawah, seperti cicit-cicit cericit burung yang bercendai diselimutu induknya karena alam telah mengajariku untuk menerima setiap lembaran kasihMu bersama sebuah permohonan. Sayangi aku dalam pekat anugerah-Mu. Aku tak punya apa-apa selai hati yang akan selalu menunggu sapa-Mu. Sapa yang gelap_kutukan_dikala aku terjaga dari tidurku, dikala sang waktu menyapa rambutku yang perlahan ditumbuhi uban ketuaan hingga aku terlelap dalam penyerahan sempurna, dalam pelukan bumi. (hal. 253) 
Seperti paparan kutipan di atas, berakhlak kepada Allah dapat ditunjukkan dengan ketundukan danmeyakini Islam sepenuhnya yang ditujukan jalan kebenaran yaitu AL-Qur;an dan Assunah. Akhlak kepada Allah adalah membawa ketenangan tersendiri di dalam hati.

\section{b. Akhlak kepada Orang Tua}

Tokoh Nidah Kirani digambarkan sebagai insan sholehah. Walaupun ia diterpa badai kekecewaan terhadap organisasi yang ia geluti, tetapi ia yang sangat menyayangi orang tuanya dengan berbakti kepadanya melalaui tingkah, laku, dan do'a. kutipan yang menggambarkan hal tersebut sebagai berikut:

"anakku Nidah Kirani, datangkah kamu ke Jakarta. Bapakmu sakit lagi. Kali ini genting!"

Begitulah secarik pesan ibuku via telepon yang diserahkan sepupuku di kontrakannya di Gedong-kuning. Betapa kurasai pesan itu begitu tegas. Kurasai ada nada perintah yang bersicepat di sana. Ya, pesan itu kurasai sangat lain dari pesan yang sudah-sudah yang biasanya hanya berupa anjuran. Seperti ini "kalau tak ada aktifitas di Kampus. Pulanglah dulu. Sakit bapakmu kambuh lagi."

Cuma begitu pesan rutinnya. Tapi pesan kali ini lain. Lebih tegas.

Maka kuputuskanlah untuk berangkat ke Jakarta dengan membawa sekeranjan kunang-kunang pikiran. (hal.169)

Tak terasa air mataku jatuh dan menggaris pipiku. Aku menangis karena aku bisa merasai bagaimana deritanya bapakku. Dan aku sendiri, hidupku sendiri, terlunta seperti kehilangan pegangan kalau kuingat lagi masalaluku, uh... betapa takdir manusia tak ada yang menduga-duga. Kukuat-kuatkan memang untuk melawan, tapi rasa lemah rasa sedih, dan rasa panik itu jua menghampiri. Keseтиа-тиа itu datang tepat dihadapan mataku. Keluargaku tengah meniti jembatan lapuk dan hanya menunggu waktu untuk ringsek dan pada akhirnya ambruk. (hal. 170)

Seperti yang telah di paparkan, Akhlak merupakan tingkah laku, budi pekerti yang melekat dalam jiwa seseorang untuk melakukan hal atau perbuatan, dan Akhlak juga sering disebut dengan moral. Tingkah laku yang baik terhadap orang tua adalah termasuk berakhlak kepada orang tua. Seperti halnya dilakukan tokoh dalam kutipan juga bagian dari berakhlak kepada orang tua.

\section{c. Akhlak dalam menerima Ketentuan Allah}

Kesabaran tokoh Nidah Kirani ketika banyak cobaan yang menerpa dirinya. Sebagaiman dalam kutipan berikut:

Awal-awal ketika menghadapi bapak yang kejang-kejangitu badan kami lemas, tapi akhirnya terbiasa juga. (hal 172)

"Tuhan, sampai kapan Kau menyiksa bapakku. Sampai kapan Kau menghabiskan seluruh keringat kami. Memang salah apa dia kepada-Mu sampai Kau begitu kejam? Sudahlah, aku saja yang menanggung. Kalau Kau ambil, ambillah dia dengan baik-baik. Tidak seperti ini. Tidak hidup tidak mati," (hal. 176-177)

Ditinjau dari paparan di atas, Akhlak dalam menerima ketentuan Allah, Seperti halnya yang dilakukan tokoh Nidah Kirani dalam menerima ketentuan Allah pada dirinya. Kesadaran akan apapun yang telah dilimpahkan Allah dan juga yakin bahwa Allah tengah menguji keimanannya atas apa yang dialaminya.

\section{PENUTUP}

Novel Tuhan Izinkan Aku Menjadi Pelacur! karya Muhidin M Dahlan adalah kisah seorang perempuan bernama Nindah 
Kirani yang saleh. Ibadah adalah rutinitasnya. Hingga pada suatu hari Nidah Kirani Nindah terjerembab suatu aliran keagamaan yang menurut warga sekitar sesat. Nidah Kiranipun dimarjinalkan. Sampai titik tertentu ia di usir dari keluarga dan kampung tersebut. Nindah putus asa dengan semua orang, maka pergaulan bebas pun menjadi pelampiasan. Dari cerita tersebut dapat diambil hikmah bahwa Allah SWT menguji hamba-Nya yang beriman melainkan untuk menjadi orang yang bertaqwa kepada Allah.

Spiritualitas adalah suatu perasaan keagamaan yang lebih mengarah pada eksistensinya sebagi manusia karena bersifat personalitas dan cakupannya pun lebih luas dari pada agama yang hanya terbatas pada ajaran-ajaran dan pertautan-pertautan. Spiritualitas dalam Konteks ini meliputi beberapa unsur fundamental yaitu: Aqidah, syariah, dan akhlak. Tiga hal dari unsur religi ini tidak dapat dipisahkan karena sangat berkaitan dengan yang lainnya.

Berdasarkan uraian tersebut menunjukan bahwa aspek spiritual yang terdapat dalam novel Tuhan Izinkan Aku Menjadi Pelacur! Adalah Aqidah, syariah, dan akhlak. Akidah terdiri dari ketauhidan dan iman kepada takdir. Syariah meliputi ibadah dan siyasah sedankan muamalah dan munakahat tidak ditemukan. Adapun akhlak mencakup akhlak kepada Allah, akhlak kepada kedua orang Tua, dan akhlak dalam menerima ketentuan Allah sedangkan perasaan malu (Al-Haya) tidak ditemukan. Selain itu tampak bahwa suatu perasaan keagamaan yang lebih mengarah pada eksistensinya sebagai manusia karena bersifat personalitas dan cakupannya pun lebih luas dari pada agama yang hanya terbatas pada ajaran-ajaran dan pertautanpertautan.

\section{DAFTAR PUSTAKA}

Ahmadi, Abu dan Noor Salimi. 2008. Dasar-dasar pendidikan Agama Islam (Untuk Perguruan Tinngi). Jakarta: Bumi Aksara

Aminuddin. 2010. Pengantar Apresiasi Karya Sastra. Bandung: Sinar Baru Algensindo

Azra, Azyumardi, dkk. 2002. Pendidikan Agama Islam pada Perguruan Tinngi

Umum. Jakarta: Departemen Agama

Depdiknas, 2006.Dua Puluh Lima Naskah Terbaik. Jakarta; Direktorat Jendral Majemen Pendidikan Dasar dan Menengah Kegiatan Peningkatan Perpustakaan Sekolah dan Pelajaran Sastra.

Iye, R., \& Susiati, S. (2018). NILAI EDUKATIF DALAM NOVEL SEBAIT CINTA DI BAWAH LANGIT KAIRO KARYA MAHMUD JAUHARI ALI (Educative Values in Sebait Cinta di Bawah Langit Kairo by Mahmud Jauhari Ali). Sirok Bastra, 6(2), 185191.

Iye, R. H. NILAI-NILAI MORAL DALAM TOKOH UTAMA PADA NOVEL SATIN MERAH KARYA BRAHMANTO ANINDITO DAN RIE YANTI. TELAGA BAHASA,(7), 2, 195-206.

Jafar. Muh, 2010. Dasar-dasar Kajian Sastra dan Penerapannya. Yogyakarta: Kanisius.

Junaedie, H. Moha. 2005. Dasar-Dasar Kajian Sastra dan Penerapannya. Ujung Pandang: CV. Putra Maspul Offset.

Kamus Besar Bahasa Indonesia, 2008: Jakarta RT. Media Pustaka Phoenix

Keraf, goris. 2002. Diksi dan Gaya Bahasa. Jakarta: PT. Gramedia Pustaka Utama.

Mangunwijaya. 2002. Pengantar Ilmu Sastra. Jakarta : PT. Gramedia. (Terjemahan Dick Hartoko)

Musthofa, 2000. Pendekatan Karya Sastra. Jakarta; Surga Tulis. 
Nurcholis, 2003. Religiutas Sastra dalam Pendekatan Struktural Genetik. Jakarta; Open Lis

Ratna, Nyoman Kutha. 2000. Teori, Metode Dan Teknik Penilitian Sastra. Denpasar : Pustaka Pelajar.

Susiati, S. (2020). The Concept Of Togetherness In The Films" Aisyah
Biarkan Kami Bersaudara" By Herwin Novianto.

Suwadah, 2011. Kajian Sastra Teori dan Praktek. Yogyakarta: Aura Pustaka

Tarigan, Henry Guntur. 2000. Pengajaran Semantik. Bandung : Angkasa.

Zainuddin dan Elizabeth, 2000. Kamus Istilah Sastra. Jakarta : Balai Pustaka. 